\title{
Design and Practice of Cooperation Platform Professional Training in Course Computer-based Mu School-enterprise
}

\author{
Jian Peng \\ ShaoGuan University, Shaoguan, Guangdong, 512000 China
}

\begin{abstract}
Essence of education is a shared resource, and educational resources from all mankind, it should be shared in humanity. If you can, whether high and low, both spatial and temporal distance can have access to quality educational resources, and then be able to complete this vision of online education. IT makes everything become possible. The following are a few famous American network teaching platforms, and if you like you can experience the charm of online teaching yourself.
\end{abstract}

Keywords-vocational education; school-enterprise cooperation; situation analysis

Computers and computer applications grow at breakneck speed toward networked, multi-functional, industry-oriented development. General from the original text, data processing is to the present text, graphics, images, sounds, movies, animation and other multimedia processing; from the original general personal computer to the Internet now, there are but just a few decades. Due to the continuous improvement of computer performance, a variety of computer software applications continue to launch such applications in various industries and home computers more popular. In China, with the further popularization of computers, computer education has also achieved great success. In today, computers began to spread, the general application operations, word processing, is already basic skills, it is general learned by people can grasp computer skills. But many industry and specialized computer applications personnel is relatively low.

\section{Mu LESSON}

"Mu lesson" For now, China's basic education is concerned, and it is still relatively high, in theory, it can boost education fair, but at the current level of development to promote is not very realistic, but also it faces many challenges. "Central AVE Museum, long Wang Zhu said that China's education information is divided into three stages, the first stage is to make teachers learn new skills, and the second stage is to allow teachers to use technology to teach, and the third stage is based on the development of new technical requirements to change teaching." At present, most of our teachers are still in the development process from the second stage to the third stage, and will make use of network resources for teaching, but not to mention the integration of network resources."

"Mu lesson" storm rises in 2011 in the United States, several teachers at Harvard, Stanford, Princeton and other schools of the quality of each school's curriculum spread on the newly created network platform, quickly attracted millions of students around the world to register. Unlike nowadays popular network open class, "Mu class" is based on big data technology, including progress in learning management, real-time online communication $\mathrm{Q} \& \mathrm{~A}$, job correcting, etc., covering the entire process of teaching a new online education.

More interesting is that this year in February, 5 "Mu Course" entered the American Council on Education Credits Referral program, students will receive college credits online elective admitted, "Mu lesson" is open into the channel by the formal education system.

"Open, or be abandoned." Shanghai Jiaotong University Vice-Chancellor Dr warned that "in the face of global quality education resources and strong cultural impact, Chinese universities must accelerate education reform, improve teaching quality, otherwise it becomes a worldclass university the risk of laboratory teaching and counseling classroom."

To meet international competition and explore the road conditions for the development of online education must be simultaneously. In May this year, Peking University, Tsinghua University, Fudan University, Shanghai Jiaotong University and other four domestic colleges and universities have joined "Mu lesson" platform for uploading courses, and accept the survival of the fittest. Meanwhile, the university curriculum shares center Shanghai, China Eastern and Western university curriculum shares alliance founded nearly two years, Chinese "Mu class" platform is to accelerate the development, actively breaks the inter-school and regional barriers, in the form of online education for domestic students it provides a richer quality courses, they can repair a corresponding credits.

\section{SCHOOL-ENTERPRISE COOPERATION}

School-enterprise cooperation is run vocational education, and it is an important way to adapt production, construction, management and service lines need skilled professionals training, vocational colleges are to seek their own development and targeted training for front-line utility 
companies' technical personnel to achieve with the market's major initiatives. Cooperative education school business model is an important direction of our school education reform. Through school-enterprise cooperation, we improve students' professional ability, so that students learn in school and business practices combine to allow schools and businesses of equipment, technologies and complementary advantages, resource sharing, and effectively improve our school education objectives targeted and effective, and improve quality of training skilled personnel.

Vocational school trains the students to reach the level of business requirements, mainly due to weak teachers in some schools, teachers lack practical experience, professional theory and practice of teaching is disjointed, scientific research and technological capabilities are difficult to meet business needs. Students from "student" to "employee" of ideological transformation process and also lack of proper understanding, leading to lack of student responsibility and professional ethics, students undergo internship process and just leave, which seriously affects the normal operation of the production; vocational schools lack management of student interns, student internship slack, so that enterprises generally reflect the risks that companies assume the problem is the too large student internships, student internships are unexpected during operation, the company has to bear all the responsibility, which is reluctant to see the situation, leading to that school-enterprise cooperation can not achieve the desired results.

\section{SCHOOL-ENTERPRISE COOPERATION PROMOTES BusinesS-TO-PRACTICE HigH STANDARDS OF TRAINING STUDENTS}

Enterprise ability to train students to repair the computer's motherboard practice is very serious, in the relatively lax school students usually learn to treat learning are very serious, the degree of mastery of knowledge also rose to a new level, corporate training mode to practice students improved student overall quality, responsibility, mastery of theoretical knowledge and hands-on skills. Business student internship training model is used for student training and management to achieve good results, in my school part of the professional promotion of this teaching and management, in the eyes of students and teachers, the school is the business, it is the company's class a shop or department, in accordance with the strict enterprise management system for disciplining students, they use project teaching or brainstorming in the teaching process, so that students individually or in groups complete a project and reach a certain knowledge and skills to enable students to grasp the purpose of improving student learning enthusiasm and overall quality, and achieved good results.

School-enterprise cooperation in running mode implies a profound practical significance. Combined with the success of our school school-enterprise cooperation mode, using the campus enterprise management and schoolenterprise cooperation we strengthen education with productive labor and social production practice, the education and the market is closely together to get rid of a single management system of school education, and establish a multi-school management system for the market economy, and overcome school system personnel training and social dislocation in the phenomenon. School-enterprise cooperation needs schools and businesses operate, support, mutual penetration, two-way intervention, complementary advantages, resource interoperability, shared interests, in order to achieve mutual benefit and win-win off both schools and enterprises in the true sense. As long as we continue to "top to bottom search", recognizing schoolenterprise cooperation for the development of vocational education reform and the profound significance of efforts to change concepts of education, vocational educations actively try a new path on the road to reform schoolenterprise cooperation, they will come out with Chinese vocational education development road characteristics.

\section{SCHOOL-ENTERPRISE INTERACTIVE MODE}

Enterprises provide internship base, equipment, raw materials, and participate in the school's teaching program developed by the company and assigned teaching professionals participating schools. Excellent business managers or technical staff gives lessons to the school teaching, both schools and enterprises promote mutual recruits, corporate engineers are into the school to teach students, and school teachers corporate in staff training, to improve the quality of staff. Schools and enterprises of both sides engage each other, so that students get skills training in the teaching process, both are to improve the professional skills of the process, both are to solve the shortage of training materials fee contradictions, and also excellent skills of students are trained, truly realize income in fertility, educating people in revenue.

\section{ORder Training, Corporate Recruit StafF, AND STUDENTS FIND JOBS}

Achieving student employment is one of the main objectives of school education, technical requirements for new employees is essential to protect corporate metabolism, and order training is an effective way to unify the two goals. Schools can enterprise technology needs, develop specialized teaching programs for corporate orders training, students complete training then enter the corresponding enterprises to achieve employment, and this is a good measure of a school-enterprise win. Orders for regular students in the first year of teaching, technical orders for the second year started training, and the third year is to enter orders for companies' internships. This will not only ensure the employment of order training, but also solve real business technology needs orders.

Establish a service for the purpose of professional development philosophy. According to the guidelines of higher vocational education, professional re-analysis of the positioning of a professional build service object, according to the IT industry, enterprise talent needs, student employment whereabouts previous analyzes are to determine the orientation of the professional service, and on 
this basis, we are to carry out demand for professional building surveys, curriculum reconstruction, construction work and other school-enterprise cooperation. Professional Services team in-depth investigation is to understand the real business talent needs, job capacity needs and typical tasks, tasks of reconstruction scenarios typical fields of study courses, starting from the job tasks, we build curriculum system based on the work process, so professional the building has a very clear point and targeted service area industries, businesses, industry specific ideas are to implement.

Establish the action-oriented teaching philosophy. According to the typical work process within the area of an enterprise and analysis of typical tasks finishing, systematic core learning areas of professional learning context, and in accordance with the six-step teaching theory, implement tasks and carrier specific project pedagogy. System design and implementation of the project pedagogy and teaching teams are to promote active learning theories and methods of teaching research tasks, design and implement projects and programs, so that action-oriented, educational philosophy student body to be truly implemented.

Establish the concept of school-enterprise cooperation system. The building can reproduce real production situations dual function of production and teaching practice teaching conditions as an important principle of teaching resources construction, it is carried out at different levels of school-enterprise cooperation. Make full use of professional teachers, technology, graduates resources, and attract enterprises to carry out multi-level cooperation. And 16 IT companies establish a two-way to undertake internships and training of teachers and employees are as the main content of the "two-way base" cooperation.

\section{A. Mechanism of part-time construction of teachers is basically established}

In school-enterprise cooperation in all fields, combined with practical training model run according to engineering, we take appropriate actions to carry out the construction of part-time teachers. First, introduce the four joint ventures undertaken lecturer teaching colleges and enterprises to jointly develop curriculum; Second, through schools and teacher training base production job swap we introduce four enterprise technical personnel longtime part-time teachers; Third human resources are by providing compensation for cooperative enterprise approach, based on professional teaching need it is flexible to recruit four part-time teachers. The appointment of a large number of part-time teachers is to effectively address the actual practice of teaching and bonding production problems and improve the level of competence of personnel training.

Personnel training programs use the tutorial system improvements. Taking into account the lack of new local university tutor, freshman, and sophomore class institution can manage, but also shift organizational design courses, but to arrange suitable off-campus internships, students find their own professional interest in the internship process, and training their professional orientation. In the junior year, the curriculum should be designed to refine the training field, focuses on training students in technical and special features. Students can choose their own instructor determined according to their professional direction (instructors primarily responsible for student learning, student counselor responsible for the daily management), rather than do the thesis advisor when selecting paper. Using tutorial system allows students to learn according to their own interests composed of a team, and improves their self-learning ability; many hobbies and expertise, high professionalism, little direction, modular are individualized according to students' interests; allow students to prepare in advance for the thesis, take experiments and practical classes well, and develop their own skills and ability to innovate.

\section{B. Improve teaching methods, strengthen the teaching staff}

Actively seek ways of teaching and research cooperation. New undergraduate colleges have no experience, faculty research forces are relatively weak, and have relatively low degree of social recognition, in this case, on the one hand we strengthen self-construction, improve the construction of school laboratories and training base, and encourage teachers to participate actively in the subject or declaration of the project, through the project of teaching, we carry out research to gain experience for foreign cooperation; We must also seize the opportunity to seek to strengthen cooperation with related businesses in the region, and actively participate in technological innovation of enterprises in the region for direct access to off-campus practice base, to a certain extent, solve the school funding tight, teaching and research equipment backwardness and lack of status quo, it can improve schools in developing innovative ability to expand the actual training conditions.

\section{SUMMARY}

Computer professionals developing has many shortcomings in the training mode, but if we continue to reform and innovation, continuous learn advanced teaching experience and successful training model, combined with the characteristics of the school, we will explore the region's economic development and social development needs of a line with computer professionals training mode, to provide a lot of talent in the region of reserves and development of information industry.

\section{ACKNOWLEDGEMENT}

(Guangdong university education [2013] No. 113), which is from Guangdong Province Education Reform Project, Guangdong Province Higher "professional comprehensive reform pilot" project; (teach high Division letter [2013] No 48.), which is from Guangdong Province college campus practice teaching base construction projects, country; Shaoguan University research focus of educational reform projects (SYJY20121305) 


\section{REFERENCES}

[1] Li Suruo Colleges of applied computer science research and practice of school-enterprise cooperation [J] software Tribune, 2014,07: 185-187.

[2] Han Yumei Co-curriculum construction of school-enterprise computer science research [J] Yanbian Education College, 2014,03: 29-31.

[3] Wang Ying school-enterprise cooperation system professionals in business English training in the application [J] overseas English, 2014,05: 85-86.
[4] Wang Yongqiang cooperation between schools and enterprises local colleges computer professional training mode [J] Fujian computer, 2014,04: 195-197.

[5] Wang Guixiang, research and investigate computer professionals based on training model of cooperation between schools and enterprises[J] Gansu Science and Technology, 2012,13: 68-69 + 110 . 